\title{
Lipid profile of subcutaneous fat, growth performance, and carcass characteristics of gilts fed with diets supplemented with ractopamine, organic chromium or subjected to energetic feed restriction
}

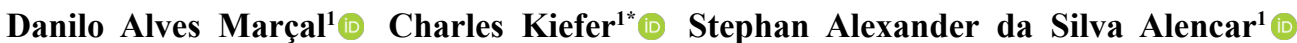 \\ Taynah Vieira Aguiar Farias ${ }^{1}$ (D) Luana Cristiane dos Santos ${ }^{1}$ (D) Luiz Henrique Viana (D) $^{1}$ \\ Leandro Fontoura Cavalheiro ${ }^{1}$ (i)
}

${ }^{1}$ Universidade Federal de Mato Grosso do Sul (UFMS), 79070-900, Campo Grande, MS, Brasil. E-mail: charles.kiefer@ufms.br. *Corresponding author.

ABSTRACT: This study identified the effects of dietary supplementation with ractopamine, chromium picolinate, chromium yeast, or an energetic feed restriction on the growth performance and lipid profile of subcutaneous fat, in late finishing gilts. Twenty genetically similar gilts with initial body weight of $105.35 \pm 4.77 \mathrm{~kg}$ and a final body weight of $131.37 \pm 5.58 \mathrm{~kg}$ were distributed in a completely randomized block design with five treatments (control; ractopamine: $20 \mathrm{ppm}$; chromium picolinate: $0.48 \mathrm{ppm}$; chromium yeast: $0.80 \mathrm{ppm}$; and energetic feed restriction: $-150 \mathrm{kcal} \mathrm{kg}^{-1}$ of metabolizable energy), with four replicates of one animal each. The experimental diets were isonutritives, except for the metabolizable energy level of the diet fed to the group subjected to energy restriction. There were no effects on the growth performance and carcass characteristics. Ractopamine and organic chromium (picolinate and yeast) supplementation increased the concentration of total polyunsaturated fatty acid. The proportion of $\alpha$-linolenic fatty acids were higher when the diets were supplemented with ractopamine or chromium yeast. The energy restriction increased the $n-6: n-3$ ratio and reduced $\alpha$-linolenic acid concentration. Therefore, ractopamine, chromium picolinate, chromium yeast supplementation, and energetic feed restriction did not affect the growth performance or carcass characteristics but altered the lipid profile of subcutaneous fat in finishing gilts. Ractopamine and organic chromium supplementation increased PUFA in the fat of finishing female pigs.

Key words: carcass characteristics, fatty acids, feed additives, organic minerals.

Perfil lipídico da gordura subcutânea, desempenho e características de carcaça de fêmeas suínas alimentadas com dietas suplementadas com ractopamina, cromo orgânico ou submetidas à restrição energética

RESUMO: Este estudo foi conduzido com o objetivo de identificar os efeitos da suplementação com ractopamina, cromo picolinato, cromo levedura, ou da restrição alimentar energética, sobre o desempenho e o perfil de ácidos graxos da gordura subcutânea de fêmeas suínas em fase final de terminação. Foram utilizadas 20 fêmeas suínas, geneticamente similares, com peso inicial de $105,35 \pm 4,77 \mathrm{~kg}$ e peso final de 131,37 $\pm 5,58 \mathrm{~kg}$, distribuidas em delineamento experimental de blocos ao acaso em cinco tratamentos (controle; ractopamina:

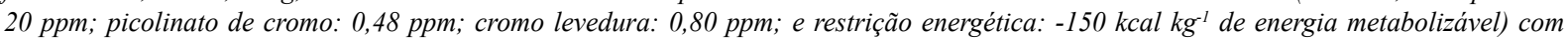
quatro repetições de um animal cada. As dietas experimentais foram isonutritivas, exceto para o nivel de energia metabolizável da dieta fornecida ao grupo submetido à restrição energética. Não houve efeito dos tratamentos sobre o desempenho e as características de carcaça. As suplementações com ractopamina e cromo orgânico (picolinato ou levedura) aumentaram a concentração de ácidos graxos poli-insaturados. A proporção do ácido $\alpha$-linolênico foi maior com a inclusão da ractopamina ou do cromo levedura na dieta. A restrição energética aumentou a proporção n-6:n-3 e reduziu a concentração do ácido $\alpha$-linolênico. As suplementações com ractopamina, picolinato de cromo, cromo levedura, ou restrição alimentar energética, não influenciaram o desempenho e as características de carcaça, mas alteraram o perfil lipídico da gordura subcutânea de fêmeas suínas. As suplementações com ractopamina e cromo orgânico aumentaram a proporção de AGPI.

Palavras-chave: ácidos graxos, aditivos nutricionais, características de carcaça, minerais orgânicos.

\section{INTRODUCTION}

Feeding ractopamine-supplemented diets for finishing pigs increases carcass lean mass and reduces the amount of carcass fat (POMPEU et al., 2017). The use of ractopamine in the diets for pigs is still allowed in Brazil; however, its use is banned in the
European Union countries, China, and Russia (NIÑO et al., 2017). Dietary supplementation with organic chromium (JACKSON et al., 2009; MARCOLLA et al., 2017) and a reduction in dietary energy density (AYMERICH et al., 2020) are among the nutritional strategies adopted to replace ractopamine and decrease fat deposition in finishing pig carcasses. 
Chromium enhances insulin activity, resulting in an increase in the glucose uptake by muscle cells, and a subsequent positive effect on pig growth performance and carcass characteristics (SALLES and JANICK, 2011). Different chromium sources are evaluated as dietary supplements; however, the results are inconclusive (LINDEMANN, 2007). Positive effects are reported with the organic sources such as chromium picolinate (LIEN et al., 2001) and chromium yeast (GUAN et al., 2000).

Energetic feed restriction is a nutritional strategy that can be adopted for finishing pigs. This technique is based on the reduction of the dietary energy without impairing growth performance or carcass characteristics in the phase in which the body's protein synthesis and accretion decrease, while the fat deposition increases (DE LANGE et al., 2001).

Nutritional strategies change the amount of fat deposited in the carcass and modulate the lipid profile of the subcutaneous fat in pigs (ALENCAR et al., 2017). Therefore, this study evaluated the effects of ractopamine, organic chromium, or the energetic feed restriction on the growth performance and the proportion of fatty acids in the subcutaneous fat of finishing gilts.

\section{MATERIALS AND METHODS}

Twenty genetically similar commercial gilts with an initial and final body weights (BW) of $105.35 \pm 4.77 \mathrm{~kg}$ and $131.37 \pm 5.58 \mathrm{~kg}$, respectively, were used. To homogenize the variability in BW among the treatments, the animals were distributed based on the initial BW to one of the five treatments [control (CON), ractopamine supplementation (RAC), chromium picolinate supplementation (CrPIC), chromium yeast supplementation (CrYST), and energy feed restriction (EFR)] using a completely randomized block design, with four replicates of one animal each.

Gilts were individually housed in a curtainsided barn with a solid concrete floor, and each pen $(1.15 \times 2.86 \mathrm{~m})$ was equipped with a single hole, dry self-feeder, and a nipple drinker for ad libitum access to feed and water. The experiment lasted for twenty-four days.

The experimental diets were offered in meal form and formulated according to ROSTAGNO et al. (2017) to meet the nutritional requirements of gilts with high genetic potential and average-tohigh growth performance from 100 to $125 \mathrm{~kg}$ of BW, except for the metabolizable energy (ME) level of the experimental diet fed to the pigs in the EFR treatment
(Table 1). The inert ingredient (kaolin) was replaced with ractopamine $(20 \mathrm{ppm})$, chromium picolinate $(0.48 \mathrm{ppm})$, or chromium yeast $(0.80 \mathrm{ppm})$ in the supplemented diets. To decrease $150 \mathrm{kcal} \mathrm{kg}^{-1}$ in the ME level of the EFR-diet, kaolin was replaced with soybean oil.

The animals were weighed without fasting at the beginning and end of the experimental period. The weight of feed offered and refused was recorded to calculate the average daily feed intake (ADFI). At the end of the experimental period, the animals underwent fasting for $8 \mathrm{~h}$ before being sent to slaughter.

The pigs were killed under the supervision of a local inspection service (SIM). The animals were subjected to electronarcosis; and subsequently bled, scalded, and eviscerated. At the end of the slaughter line, the carcass weights were recorded. Backfat thickness, longissimus dorsi muscle depth, and lean percentage were measured using a probe (Hennessy Granding System) inserted between the last thoracic and first lumbar vertebrae $5 \mathrm{~cm}$ from the middle line on the left side of the hot carcass (BRIDI and SILVA, 2007). Subcutaneous fat samples were collected at the $\mathrm{P} 2$ point (ALENCAR et al., 2017), before carcass chilling. The samples were packed, identified, and frozen until they were prepared for fatty acid profile analyses.

Lipid extraction and fatty acid methylation was performed according to HARA and RADIN (1978). The separation and detection of the fatty acids were performed using gas-liquid chromatography (Shimadzy CG-2010) with a flame ionization detector (FID), "split/split less" injector, in fused silica capillary column $(30 \mathrm{~m} \times 0.25 \mathrm{~mm})$ with BPX70 (70\% Cyanopropylpolysilphenylenesiloxane). The parameters were fixed according to ALENCAR et al. (2017).

Data on growth performance, quantitative carcass characteristics, and fatty acid concentration were subjected to variance analysis using PROC GLM (SAS Institute, Inc, Cary, NC, USA), considering the nutritional strategies as fixed effects. Hot carcass weight was used as a co-variable for quantitative carcass characteristics. Differences among means were compared using the Student-Newman-Keuls (SNK) test. The significance level was set at 5\%.

\section{RESULTS AND DISCUSSION}

There were no effects $(\mathrm{P}>0.05)$ on the growth performance and carcass characteristics, for the evaluated variables (Table 2). The lack of an effect of ractopamine on the growth performance could be 
Table 1 - Centesimal and nutritional compositional of the experimental diets.

\begin{tabular}{|c|c|c|c|c|c|}
\hline \multirow[t]{2}{*}{ Ingredients, \% } & \multicolumn{5}{|c|}{ 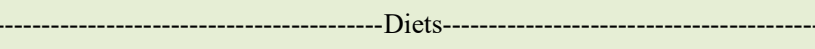 } \\
\hline & $\mathrm{CON}$ & RAC & Cr PIC & Cr YST & EFR \\
\hline Corn, $7.86 \%$ & 81.17 & 81.17 & 81.17 & 81.17 & 81.17 \\
\hline Soybean meal, $46.5 \%$ & 14.23 & 14.23 & 14.23 & 14.23 & 14.23 \\
\hline Dicalcium phospate & 0.966 & 0.966 & 0.966 & 0.966 & 0.966 \\
\hline Limestone & 0.621 & 0.621 & 0.621 & 0.621 & 0.621 \\
\hline L-Lysine-HCL & 0.382 & 0.382 & 0.382 & 0.382 & 0.382 \\
\hline Salt & 0.355 & 0.355 & 0.355 & 0.355 & 0.355 \\
\hline Vit + min premix $^{1}$ & 0.150 & 0.150 & 0.150 & 0.150 & 0.150 \\
\hline Inert (kaolin) & 0.100 & 0.000 & 0.100 & 0.050 & 1.900 \\
\hline L-Threonine & 0.097 & 0.097 & 0.097 & 0.097 & 0.097 \\
\hline DL-Methionine & 0.085 & 0.085 & 0.085 & 0.085 & 0.085 \\
\hline L-Tryptophan & 0.038 & 0.038 & 0.038 & 0.038 & 0.038 \\
\hline Ractopamine & 0.000 & 0.100 & 0.000 & 0.000 & 0.000 \\
\hline Chromium picolinate $^{2}$ & 0.000 & 0.000 & 0.0004 & 0.000 & 0.000 \\
\hline Chromium yeast & 0.000 & 0.000 & 0.000 & 0.050 & 0.000 \\
\hline Soybean oil & 1.800 & 1.800 & 1.800 & 1.800 & 0.000 \\
\hline \multicolumn{6}{|c|}{ 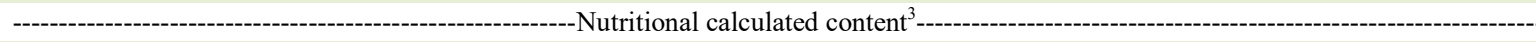 } \\
\hline Crude protein, $\%$ & 13.50 & 13.50 & 13.50 & 13.50 & 13.50 \\
\hline Metabolizable energy, kcal kg ${ }^{-1}$ & 3,350 & 3,350 & 3,350 & 3,350 & 3,200 \\
\hline SID Lys, \% & 0.811 & 0.811 & 0.811 & 0.811 & 0.811 \\
\hline SID Met + cys, $\%$ & 0.487 & 0.487 & 0.487 & 0.487 & 0.487 \\
\hline SID Thr, $\%$ & 0.527 & 0.527 & 0.527 & 0.527 & 0.527 \\
\hline SID Trp, $\%$ & 0.162 & 0.162 & 0.162 & 0.162 & 0.162 \\
\hline Calcium, \% & 0.545 & 0.545 & 0.545 & 0.545 & 0.545 \\
\hline STTD Phosphorus, \% & 0.262 & 0.262 & 0.262 & 0.262 & 0.262 \\
\hline Sodium, $\%$ & 0.160 & 0.160 & 0.160 & 0.160 & 0.160 \\
\hline
\end{tabular}

CON - Control; RAC - Ractopamine (20 ppm); Cr PIC - Chromium Picolinate (0.48 ppm); Cr YST - Chromium Yeast (0.80 ppm); EFR - Energetic Feed Restriction.

${ }^{1}$ Content per kilogram of product: Vitamin A (min): 5,000,000 IU kg${ }^{-1}$, Vitamin D3 (min): 1,000,000 IU kg-1, Vitamin E (min): 25,000 IU kg $\mathrm{kg}^{-1}$ Vitamin K3 (min) ): 3,000 mg kg-1, Vitamin B1 (min): 1,500 mg kg-1, Vitamin B2 (min): 4,000 mg kg-1, Vitamin B6 (min): 1,500 mg kg${ }^{-1}$, Vitamin B12 (min): 18,000 mg kg${ }^{-1}$, Niacin (min): $18 \mathrm{~g} \mathrm{~kg}^{-1}$, Pantothenic Acid (min): 9,200 mg kg-1, Folic Acid (min): $500 \mathrm{mg} \mathrm{kg}{ }^{-1}$, Selenium (min): $300 \mathrm{mg} \mathrm{kg}{ }^{-1}$, Iron (min): $100 \mathrm{~g} \mathrm{~kg}^{-1}$, Copper (min): $30 \mathrm{~g} \mathrm{~kg}^{-1}$, Manganese (min): $80 \mathrm{~g} \mathrm{~kg}{ }^{-1}, \mathrm{Zinc}(\mathrm{min}): 160$ $\mathrm{g} \mathrm{kg}^{-1}$, Iodine (min): $2000 \mathrm{mg} \mathrm{kg}^{-1}$.

${ }^{2}$ Purity level of chromium picolinate: $12.1 \%$.

${ }^{3}$ Values calculated based on the nutritional composition of raw materials (ROSTAGNO et al., 2017).

attributed to the lack of adjustments in the amino acid levels of the RAC diets. An increase in the level of amino acids is recommended in diets supplemented with ractopamine, for providing the additional nutrients required to cater to the higher amount of protein synthesis stimulated by ractopamine (SCHINCKEL et al., 2003). However, diets without amino acid adjustments have shown to improve feed efficiency and decrease backfat thickness in finishing pigs (MARÇAL et al., 2015). The effects of dietary chromium sources on the growth performance and tissue deposition are variable, ranging from no effects (LINDEMANN, 2007) to better feed conversion, greater muscle deposition, and less carcass fat (LIEN et al., 2001). Similar responses for growth performance and carcass characteristics were observed in the CON and EFR groups; therefore, finishing gilts can be subjected to EFR of up to $150 \mathrm{kcal} \mathrm{kg}^{-1}$ without any damage to these traits.

Ractopamine supplementation decreased $(\mathrm{P}<0.05)$ the proportion of oleic acid, $(\mathrm{C} 18: 1 \mathrm{n} 9)$ when compared to that of $\mathrm{CON}, \mathrm{Cr}$ PIC, and EFR (Table 3). RAC decreased $(\mathrm{P}<0.05)$ the proportion of monounsaturated fatty acids (MUFAs) and increased $(\mathrm{P}<0.05)$ that of $\alpha$-linoleic acid $(\mathrm{C} 18: 3 \mathrm{n} 3)$ and polyunsaturated fatty acid (PUFA), compared to the levels in CON and EFR. Ractopamine interacts with the beta-adrenergic receptors on the cellular 
Table 2 - Growth performance and carcass characteristics of gilts fed diets supplemented with ractopamine, organic chromium or subjected to energetic feed restriction.

\begin{tabular}{|c|c|c|c|c|c|c|c|}
\hline Variables & $\mathrm{CON}$ & RAC & Cr PIC & Cr YST & EFR & $\mathrm{CV}, \%$ & P value* \\
\hline Initial BW, kg & 105.3 & 105.7 & 105.0 & 105.4 & 105.5 & 4.96 & 1.00 \\
\hline Final BW, kg & 130.9 & 134.9 & 130.4 & 131.6 & 128.8 & 4.42 & 0.76 \\
\hline ADFI, kg & 3.32 & 3.21 & 3.06 & 3.27 & 3.03 & 7.59 & 0.40 \\
\hline $\mathrm{ADG}, \mathrm{kg}$ & 1.07 & 1.22 & 1.06 & 1.09 & 0.97 & 12.69 & 0.32 \\
\hline $\mathrm{F}: \mathrm{G}$ & 3.10 & 2.63 & 2.89 & 3.00 & 3.12 & 11.93 & 0.31 \\
\hline CPI, g day ${ }^{-1}$ & 448.2 & 433.4 & 413.1 & 441.5 & 409.1 & 7.64 & 0.41 \\
\hline LysI, g day ${ }^{-1}$ & 26.9 & 26.0 & 24.8 & 26.5 & 24.6 & 7.65 & 0.41 \\
\hline MEI, Mcal day ${ }^{-1}$ & 11.1 & 10.8 & 10.3 & 11.0 & 9.7 & 7.67 & 0.19 \\
\hline $\mathrm{HCW}, \mathrm{kg}$ & 99.3 & 102.0 & 98.1 & 99.4 & 97.6 & 4.72 & 0.79 \\
\hline Loin depth, mm & 72.7 & 74.5 & 69.8 & 72.2 & 69.8 & 7.26 & 0.75 \\
\hline Lean, $\%$ & 52.4 & 57.3 & 57.4 & 55.6 & 54.6 & 4.51 & 0.07 \\
\hline Backfat thickness, mm & 17.8 & 14.8 & 14.5 & 17.0 & 17.8 & 18.81 & 0.41 \\
\hline
\end{tabular}

CON - Control; RAC - Ractopamine (20 ppm); Cr PIC - Chromium Picolinate (0.48 ppm); Cr YST - Chromium Yeast (0.80 ppm); EFR - Energetic Feed Restriction. ADFI - Average Daily Feed Intake; ADG - Average Daily Gain; F:G - Feed Conversion; CPI - Crude Protein Intake; LysI - Digestible Lysine Intake; MEI - Metabolizable Energy Intake; HWC - Hot Carcass Weight.

membranes and induces lipogenic reduction, while stimulating protein synthesis (ALMEIDA et al., 2012). The synthesis of muscular tissue requires energy and nutrients. This reduces the availability of substrates for de novo synthesis, which produces palmitic acid (C16:0), which is elongated to stearic acid (C18:0), followed by conversion to MUFA by the enzyme $\Delta^{9}$-desaturase to form palmitoleic $(\mathrm{C} 16: 1)$

Table 3 - Lipid profile of subcutaneous fat of gilts fed diets supplemented with ractopamine, organic chromium or subjected to energetic feed restriction.

\begin{tabular}{|c|c|c|c|c|c|c|c|}
\hline Lipid profile & $\mathrm{CON}$ & RAC & CrPIC & CrLEV & EFR & $\mathrm{CV}, \%$ & P-value \\
\hline C12:0 (Lauric acid) & 0.05 & 0.06 & 0.05 & 0.06 & 0.06 & 28.9 & 0.55 \\
\hline C14:0 (Myristic acid) & 1.24 & 1.22 & 1.12 & 1.19 & 1.22 & 8.6 & 0.10 \\
\hline C16:0 (Palmitic acid) & 24.82 & 24.55 & 23.58 & 24.67 & 24.63 & 5.5 & 0.29 \\
\hline C16:1 (Palmitoleic acid) & $1.64^{\mathrm{ab}}$ & $1.50^{\mathrm{ab}}$ & $1.34^{\mathrm{b}}$ & $1.43^{\mathrm{ab}}$ & $1.81^{\mathrm{a}}$ & 20.2 & 0.03 \\
\hline C18:0 (Stearic acid) & 13.62 & 13.39 & 13.75 & 13.55 & 13.42 & 12.0 & 0.99 \\
\hline C18:1n9 (Oleic acid) & $39.07^{\mathrm{a}}$ & $36.52^{\mathrm{c}}$ & $38.20^{\mathrm{ab}}$ & $36.92^{\mathrm{bc}}$ & $38.37^{\mathrm{ab}}$ & 3.8 & $<0.01$ \\
\hline C18:2n6 (Linoleic acid) & 15.34 & 18.14 & 17.25 & 17.83 & 16.10 & 12.9 & 0.06 \\
\hline C18:3n6 ( $\gamma$-Linolenic acid $)$ & 0.05 & 0.07 & 0.08 & 0.04 & 0.07 & 77.4 & 0.35 \\
\hline C18:3n3 ( $\alpha$-Linolenic acid) & $0.64^{\mathrm{bc}}$ & $0.76^{\mathrm{a}}$ & $0.71^{\mathrm{ab}}$ & $0.78^{\mathrm{a}}$ & $0.59^{c}$ & 13.6 & 0.01 \\
\hline C20:3n6 (Dihomo- $\gamma$-Linolenic acid) & 0.08 & 0.09 & 0.07 & 0.08 & 0.08 & 21.6 & 0.34 \\
\hline C20:4n6 (Arachidonic acid) & 0.19 & 0.17 & 0.19 & 0.18 & 0.17 & 53.4 & 0.96 \\
\hline C20:3n3 (Eicosatrienoic acid) & 0.13 & 0.12 & 0.11 & 0.12 & 0.10 & 30.3 & 0.47 \\
\hline SFA & 40.98 & 40.77 & 40.02 & 40.81 & 40.75 & 6.1 & 0.93 \\
\hline UFA & 59.02 & 59.23 & 59.98 & 59.19 & 59.25 & 4.2 & 0.93 \\
\hline MUFA & $42.04^{\mathrm{a}}$ & $39.40^{\mathrm{b}}$ & $40.91^{\mathrm{ab}}$ & $39.50^{\mathrm{b}}$ & $41.61^{\mathrm{a}}$ & 3.7 & $<0.01$ \\
\hline PUFA & $16.97^{\mathrm{b}}$ & $19.83^{\mathrm{a}}$ & $19.07^{\mathrm{a}}$ & $19.69^{\mathrm{a}}$ & $17.65^{\mathrm{b}}$ & 11.8 & 0.04 \\
\hline PUFA:SFA & 0.41 & 0.49 & 0.48 & 0.49 & 0.44 & 17.0 & 0.18 \\
\hline Omega 6:omega 3 & $21.95^{\mathrm{b}}$ & $22.55^{\mathrm{b}}$ & $22.88^{b}$ & $21.76^{\mathrm{b}}$ & $25.59^{\mathrm{a}}$ & 5.9 & $<0.01$ \\
\hline
\end{tabular}

CON - Control; RAC - Ractopamine (20 ppm); Cr PIC - Chromium Picolinate (0.48 ppm); Cr YST - Chromium Yeast (0.80 ppm); EFR - Energetic Feed Restriction. SFA - Saturated Fatty Acids; UFA - Unsaturated Fatty Acids; MUFA - Monounsaturated Fatty Acids; PUFA - Polyunsaturated Fatty Acids.

Means followed by different letters on the same line differ from each other $(\mathrm{P}<0.05)$ using the Student-Newman-Keuls test $(\mathrm{SNK})$. 
and oleic (C18:1n9) acids (DURAN-MONTGÉ et al., 2010; MAPIYE et al., 2012). RAC exhibited no effects on the growth performance and carcass characteristics; however, it could have affected the energy partition level.

The lipid profiles of the subcutaneous fat in animals fed diets supplemented with Cr PIC was similar $(\mathrm{P}>0.05)$ to that in animals fed $\mathrm{CON}$, except for the PUFA proportion, which was higher $(\mathrm{P}<0.05)$ in the $\mathrm{Cr}$ PIC group. The $\mathrm{Cr}$ PIC supplementation reduced $(\mathrm{P}<0.05)$ the concentration of palmitoleic acid $(\mathrm{C} 16: 1)$ and increased $(\mathrm{P}<0.05)$ the concentration of $\alpha$-linolenic acid (C18:3n3), when compared to that in EFR. Compared to CON supplementation, the $\mathrm{Cr}$ YST reduced $(\mathrm{P}<0.05)$ the proportion of oleic acid (C18: 1n9) and MUFA and increased $(\mathrm{P}<0.05)$ the proportion of $\alpha$-linolenic acid (C18: $3 \mathrm{n} 3)$ and PUFA. The proportion of $\alpha$-linolenic acid (C18: 3n3) was higher $(\mathrm{P}<0.05)$ and that of MUFA was lower $(\mathrm{P}<$ 0.05) with Cr YST than with EFR supplementation; this did not differ significantly $(\mathrm{P}>0.05)$ from ractopamine or $\mathrm{Cr}$ PIC supplementations. Chromium increases cellular sensitivity to insulin and results in a greater cellular uptake of glucose, which provides more energy for metabolism (JACKSON et al., 2009). However, the effects of chromium supplementation on the lipid profile are inconsistent and vary with the source, dosage, and supplementation period (RODRIGUES et al., 2020). In this study, there were no differences in the lipid profiles between the two sources of chromium, when compared to that in $\mathrm{CON}$ and Cr YST; however, they had greater effects on the amount of fatty acids.

The animals fed on the EFR diet had a higher $(\mathrm{P}<0.05)$ proportion of palmitoleic acid (C16:1), compared to animals that received Cr PIC, a higher $(\mathrm{P}<0.05)$ proportion of oleic acid $(\mathrm{C} 18: 1 \mathrm{n} 9)$, compared to the animals that received RAC, and a higher $(\mathrm{P}<0.05)$ proportion of MUFA, compared to the animals that received RAC and Cr YST. A portion of the fatty acids in the fat deposited in the carcass is derived from the diet. The other parts have endogenous production, through de novo synthesis, using carbon skeletons of the absorbed and unused carbohydrates and proteins as precursors (LEWIS and SOUZA, 2000). The EFR diet increased $(\mathrm{P}<0.05)$ the omega 6:omega 3 ratio compared to that in the other treatments. This can be attributed to the non-inclusion of soybean oil in this diet, which is rich in $\alpha$-linolenic acid (C18:3n3). EFR diet increases the proportion of PUFA and reduces the levels of saturated fatty acids (SFA), when compared to the animals on the control diet (APPLE et al., 2009).

\section{CONCLUSION}

Supplementation with ractopamine, chromium picolinate, chromium yeast, or energy feed restriction did not influence the growth performance and quantitative carcass characteristics; however, it altered the lipid profile of the subcutaneous fat in finishing female pigs.

Supplementation with ractopamine and organic chromium increased the proportion of PUFA in the fat of finishing female pigs.

\section{ACKNOWLEDGEMENTS}

The authors thank the Fundação de Apoio ao Desenvolvimento do Ensino, Ciência e Tecnologia do Estado de Mato Grosso do Sul (FUNDECT), Conselho Nacional de Desenvolvimento Científico e Tecnológico (CNPq), Universidade Federal de Mato Grosso do Sul (UFMS), and Coordenação de Aperfeiçoamento de Pessoal de Nível Superior - Brasil (CAPES; Finance Code 001) for the financial support in the execution of the research project.

\section{BIOETHICS AND BIOSAFETY COMMITTEE} APPROVAL

The Ethics Committee on the Use of Animals of Universidade Federal do Mato Grosso do Sul approved this project under protocol $\mathrm{n}^{\circ} 875 / 2017$.

\section{DECLARATION OF CONFLICT OF} INTEREST

The authors declare no conflict of interest.

\section{AUTHORS' CONTRIBUTIONS}

All authors contributed equally for the conception and writing of the manuscript. All authors critically revised the manuscript and approved of the final version.

\section{REFERENCES}

ALENCAR, S. A. S. et al. Net energy level on the lipid profile of pork. Ciência Rural, v.47: 10, e20170189, 2017. Available from: $<$ http://dx.doi.org/10.1590/0103-8478cr20170189>. Accessed: Feb. 02, 2019. doi: 10.1590/0103-8478cr20170189.

ALMEIDA, V. V. et al. Ractopamine as a metabolic modifier feed additive for finishing pigs: A review. Brazilian Archives of Biology and Technology, v.55, p.445-456, 2012. Available from: $<$ https://www.scielo.br/pdf/babt/v55n3/16.pdf>. Accessed: Jan. 30, 2021. doi: 10.1590/S1516-89132012000300016.

APPLE, J. K. et al. Interactive effects of dietary fat source and slaughter weight in growing-finishing swine: III. Carcass and fatty acid compositions. Journal of Animal Science, v.88, p.14411454, 2009. Available from: <https://doi.org/10.2527/jas.20081455>. Accessed: Mar. 03, 2019. doi: 10.2527/jas.2008-1455. 
AYMERICH et al. The implications of nutritional strategies that modify dietary energy and lysine for growth performance in two different swine production systems. Animals, v.10, p.1638, 2020. Available from: <https://www.mdpi.com/2076-2615/10/9/1638>. Accessed: Feb. 03, 2021. doi: 10.3390/ani10091638.

BRIDI, A. M.; SILVA, C. A. Métodos de avaliação de carcaça e da carne suína. Londrina, Midiograf. 97p. 2007.

DE LANGE, C. F. M. et al. Protein, fat and bone tissue growth in swine. In: A. J. Lewis and L. L. Southern, editors, Swine nutrition. 2nd ed. CRC Press, Washington, DC. p.65-81, 2001.

DURAN-MONTGÉ, P. et al. De novo fatty acid synthesis and balance of fatty acids of pigs fed different fat sources. Livestock Science, v.132, p.157-164, 2010. Available from: <https://www. sciencedirect.com/science/article/abs/pii/S1871141310002064>. Accessed: Jul. 24, 2020. doi: 10.1016/j.livsci.2010.05.017.

GUAN, X. et al. High chromium yeast supplementation improves glucose tolerance in pigs by decreasing hepatic extraction of insulin. The Journal of nutrition, v.130, p.1274-1279, 2000. Available from: <https://academic.oup.com/jn/article/130/5/1274/4686584>. Acessed: Oct. 04, 2020. doi: 10.1093/jn/130.5.1274.

HARA, A.; RADIN, N. S. Lipid extraction of tissues with lowtoxicity solvent. Analytical Biochemistry, v.90, p.420-426, 1978. Available from: <http://dx.doi.org/10.1016/0003-2697(78)900465>. Accessed: Apr. 09, 2017. doi: 10.1016/0003-2697(78)90046-5.

JACKSON, A. R. et al. The effect of chromium as chromium propionate on growth performance, carcass traits, meat quality, and the fatty acid profile of fat from pigs fed no supplemented dietary fat, choice white grease, or tallow. Journal of Animal Science, v.87, p.4032-4041, 2009. Available from: <https://academic.oup. com/jas/article-lookup/doi/10.2527/jas.2009-2168>. Accessed: Oct. 10, 2018. doi: $0.2527 /$ jas.2009-2168.

MARCOLLA, C. S. et al. Chromium, CLA, and ractopamine for finishing pigs. Journal of Animal Science, v.95, p.4472-4480, 2017. Available from: $<$ https://academic.oup.com/jas/article-abstr act/95/10/4472/4771992?redirectedFrom=fulltext $>$. Accessed: Jul. 01, 2020. doi: $10.2527 /$ jas 2017.1753 .

LEWIS, A. J.; SOUTHERN, L. L. Swine Nutrition. CRC press. 2000.

LIEN, T. F. et al. Effect of supplemental levels of chromium picolinate on the growth performance, serum traits, carcass characteristics and lipid metabolism of growing-finishing pigs. Animal Science, v.72, p.289-296, 2001. Available from : <https:// www.cambridge.org/core/journals/animal-science/article/effect- of-supplemental- evels-of-chromium-picolinate-on-the-growthperformance-serum-traits-carcass- characteristics-and-lipidmetabolism-of-growingfinishing-pigs/51CA850FFDBDAFE0 1725FD17FE14B951>. Accessed: Sep. 19, 2020. doi: 10.1017/ S1357729800055788.

LINDEMANN, M. D. Use of chromium as an animal feed supplement. In: The Nutritional Biochemistry of Chromium (III). J. B. Vincent, ed. Elsevier, New York, 2007.

MARÇAL, D. A. et al. Ractopamina em dietas sem ajustes aminoacídicos para suínos machos castrados em terminação. Revista Ceres, v.62, n.3, p.259-264, 2015. Available from: <https://www. scielo.br/pdf/rceres/v62n3/0034-737X-rceres-62-03-00259.pdf $>$. Accessed: Oct. 01, 2020. doi: 10.1590/0034-737X201562030005.

MAPIYE, C. et al. The labile lipid fraction of meat: From perceived disease and waste to health and opportunity. Meat science, v.92, n.3, 210-220, 2012. Available from: <https://www.sciencedirect. com/science/article/abs/pii/S0309174012001106> . Accessed: Jan. 14, 2020. doi: 10.1016/j.meatsci.2012.03.016Get.

NIÑO, A. M. M. et al. The challenges of ractopamine use in meat production for export to European Union and Russia. Food Control, v.72, p.289-292, 2017. Available from: <https://www. sciencedirect.com/science/article/pii/S0956713515302371>. Accessed: Mar. 04, 2018. doi: 10.1016/j.foodcont.2015.10.015.

POMPEU, M. A. et al. A multivariate approach to determine the factors affecting response level of growth, carcass, and meat quality traits in finishing pigs fed ractopamine. Journal of animal science, v.95, p.1644-1659, 2017. Available from: <https://academic.oup. com/jas/article-abstract/95/4/1644/4702154?redirectedFrom=fullt ext>. Accessed: Dec. 29, 2018. doi:10.2527/jas.2016.1181.

RODRIGUES, G. P. et al. Combined supplementation of chromium-yeast and selenium-yeast on finishing barrows. Ciência Rural, v.50:11, e20190406, 2020. Available from: <https://www. scielo.br/pdf/cr/v50n11/1678-4596-cr-50-11-e20190406.pdf >. Accessed: Feb. 02, 2021. doi: 10.1590/0103-8478cr20190406.

ROSTAGNO, H. S. et al. Tabelas brasileiras para aves e suínos: composição de alimentos e exigências nutricionais. 4. ed. Viçosa: Editora UFV. 2017. 488p.

SCHINCKEL, A. P. et al. Development of a model to describe the compositional growth and dietary lysine requirements of pig fed ractopamine. Journal of Animal Science, v.81, p.1106-1119, 2003. Available from: <https://academic.oup.com/jas/articleabstract/81/5/1106/4789967>. Accessed: Sep. 23, 2020. doi: $10.2527 / 2003.8151106 x$. 